
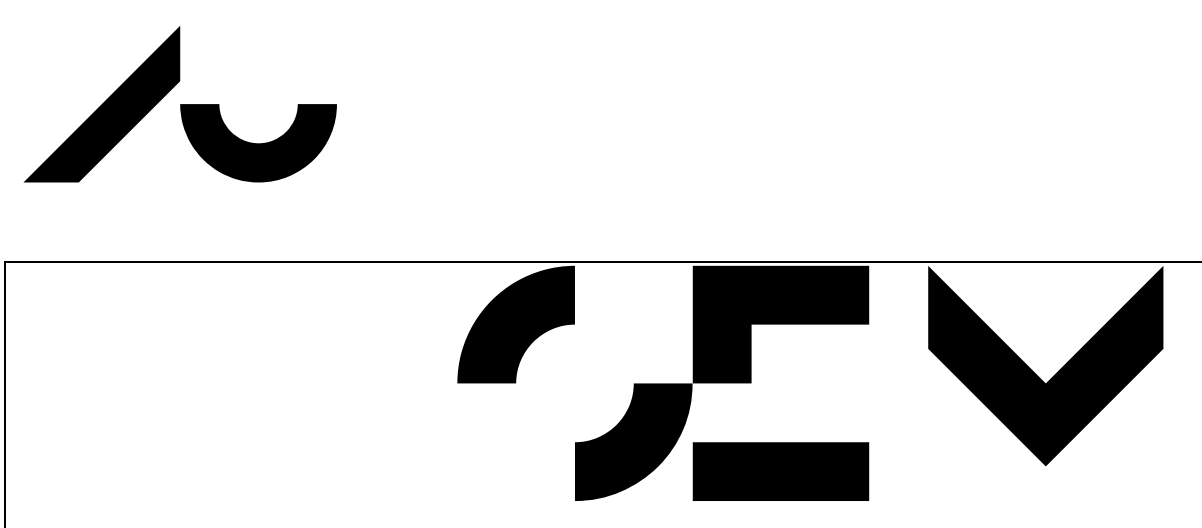

Economics Working Paper

2010-6

\title{
The Theoretical Equivalent of Empirically Measurable Exporter Productivity when Firms are Heterogeneous
}

Philipp J.H. Schröder and Allan Sørensen

Bartholins Allé 10, Building 1322

DK-8000 Aarhus C - Denmark

Phone +458942 1610

Mail: oekonomi@econ.au.dk

Web: www.econ.au.dk 

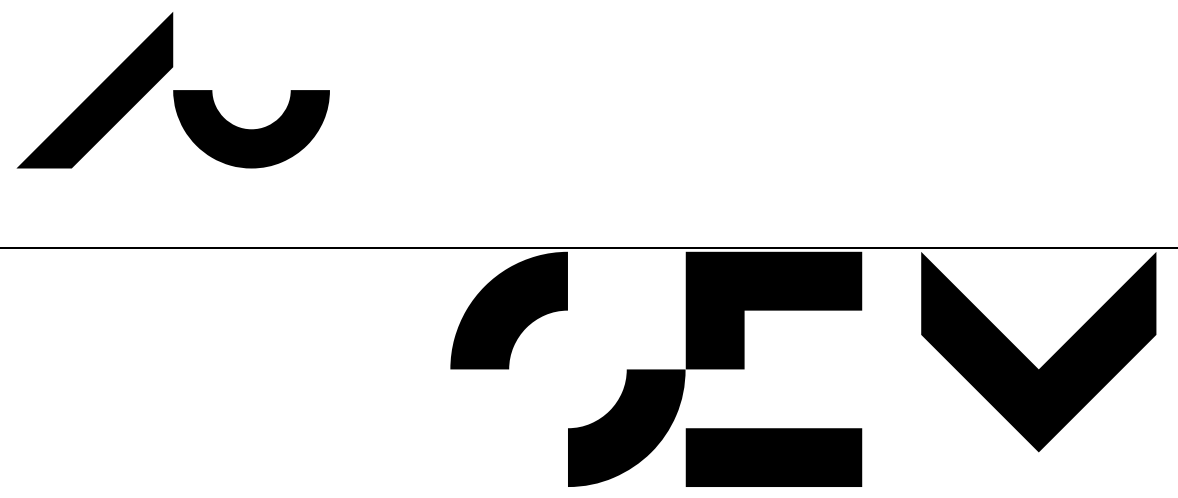

\section{Economics Working Paper}

2010-6

School of Economics and Management

Aarhus University

Bartholins Allé 10, Building 1322

DK-8000 Aarhus C - Denmark

Phone +4589421610

Mail: oekonomi@econ.au.dk

Web: www.econ.au.dk 


\title{
The Theoretical Equivalent of Empirically Measurable Exporter Productivity when Firms are Heterogeneous
}

\author{
Philipp J.H. Schröder* Allan Sørensen ${ }^{\dagger}$
}

May 2010

\begin{abstract}
The marginal costs based representation of firm productivity in the Melitz [Melitz, M.J., 2003. The impact of trade on intra-industry reallocations and aggregate industry productivity. Econometrica 71 (6), 1695-1725] model, predicts positive exporter productivity premia. We show that this prediction is reversible when computing the theoretical equivalent of the empirically measurable productivity expression (value added per worker) in the model. The paper discusses implications of this finding for empirical research.
\end{abstract}

JEL: F12, F13, F15

Keywords: Intra-industry trade, firm productivity, heterogeneous firms.

*Department of Economics, Aarhus School of Business, Aarhus University, Denmark. Tel.: +45 8948 6392, E-mail: psc@asb.dk.

$\dagger$ School of Economics and Management, Aarhus University, Denmark. Tel.: +45 8942 1573, E-mail: asoerensen@econ.au.dk.

Note: A longer companion paper that includes the Bernard, Eaton, Jensen and Kortum (AER, 2003) firm-heterogeneity specification is circulating under the title "Second Thoughts on Exporter Productivity Premia"

Acknowledgements: We wish to thank Hartmut Egger, Simon Evenett, Gabriel Felbermayr, John Haltiwanger, Jan Guldager Jørgensen, Samuel Kortum, Udo Kreickemeier, Thierry Mayer and Marc Melitz for helpful comments and discussions. Philipp Schröder acknowledges financial support from the Danish Agency for Science, Technology and Innovation (grant no. 275-06-0025). 


\section{Introduction}

Starting with Bernard and Jensen (1995), the productivity differences between exporters and non-exporters have been a prominent research topic in international economics. Melitz (2003), by introducing firm heterogeneity into an intra-industry trade model, reconciles the empirical regularity of productivity differences with the theory of international trade. This note shows, however, that switching from the theoretical to the empirical measure of firm productivity, weakens and may even reverse the exporter productivity premium established in Melitz (2003).

We investigate the empirical relevant productivity measure, namely valueadded per employee, in a Melitz (2003) heterogeneous firms model. While empirical measures include average cost information, previous theoretical work represents firm productivity by marginal cost alone. More precisely the theoretical work ranks firms by marginal productivity, i.e., $\varphi$, in the Melitz (2003) notation, where accordingly marginal cost is $w / \varphi$. We examine the difference between the theoretical - marginal cost-based - concept and the empirical feasible - average cost-based - measure of productivity. We show that once the theoretical framework is used to compute the measured labor productivity expression of empirical studies, the productivity of nonexporters will exceed that of exporters in proximity - proximity in terms of marginal productivity - to the export-indifferent firm. The reason is that in the Melitz (2003) setting, fixed export costs drive up the average costs of exporters. Thus, the theory does not in general predict that exporters have higher productive than non-exporters.

Accordingly, this note has two central messages. First, the Melitz (2003) model is in fact consistent also with the exceptions of negative exporter productivity premia found in the empirical literature. Second, the note emphasizes the importance of treating fixed and variable costs explicitly when 
examining firm productivity.

The next section establishes the ranking of exporters and non-exporters in terms of measured labor productivity. Section 3 discusses implications for empirical research strategies. Section 4 concludes.

\section{Firm-level productivity}

As in Melitz (2003), the demand for each variety is $q=Q\left(\frac{p}{P}\right)^{-\sigma}$ where $p$ is the price of the variety, $Q$ the aggregate demand, $P$ the price index and $\sigma$ the elasticity of demand. Monopolistic firms have production technologies with increasing returns due to fixed costs of production $(f)$ and a constant marginal productivity $(\varphi)$. To enter the industry, firms invest $\left(f_{E}\right)$ in developing a blue-print. ${ }^{1}$ Variation in blueprints determines firm heterogeneity, i.e. variation in blueprints is represented by differences in marginal productivity $(\varphi)$. Firms entering the export market face fixed export market access $\operatorname{costs}\left(f_{x}\right)$ and iceberg trade costs $(\tau \geq 1)$.

Given constant elasticity of substitution, firms set prices as a constant markup $\left(\frac{\sigma}{\sigma-1}\right)$ on marginal costs. Profits on the domestic and foreign markets are

$$
\begin{aligned}
\Pi^{\text {Dom }} & =\left(p-\frac{w}{\varphi}\right) Q\left(\frac{p}{P}\right)^{-\sigma}-w f \\
& =\frac{1}{\sigma-1}\left(\frac{w}{\varphi}\right)^{1-\sigma}\left(\frac{\sigma}{\sigma-1}\right)^{-\sigma} Q P^{\sigma}-w f \\
\Pi^{\operatorname{Exp}} & =\left(p^{*}-\tau \frac{w}{\varphi}\right) Q^{*}\left(\frac{p^{*}}{P^{*}}\right)^{-\sigma}-w f_{x} \\
& =\frac{1}{\sigma-1}\left(\tau \frac{w}{\varphi}\right)^{1-\sigma}\left(\frac{\sigma}{\sigma-1}\right)^{-\sigma} Q^{*} P^{* \sigma}-w f_{x},
\end{aligned}
$$

\footnotetext{
${ }^{1}$ Firms enter the industry until the expected value of profits equals the sunk investment cost, $f_{E}$. Following the literature, we ignore time discounting; instead, firms face a constant probability of death $(\delta)$.
} 
where $*$ denotes foreign market variables and $w$ is the wage rate. Exportindifferent firms are defined by $\Pi^{\operatorname{Exp}}=0$, and firms indifferent to leave the industry are defined by $\Pi^{\text {Dom }}=0 .^{2}$

The theoretical literature, starting with Melitz (2003), states productivity rankings of firms in terms of the heterogeneity parameter, namely, marginal productivity, $\varphi$. Yet in empirical work, marginal productivity is not an operational concept. Accordingly, we present here - in line with empirical approaches - a productivity measure of value added over factor use. In the specific model at hand, this reads revenue per worker. Thus measured labor productivity, depending on the firm's market presence, is

$$
\rho=\left\{\begin{array}{cc}
\frac{p Q\left(\frac{p}{P}\right)^{-\sigma}}{\frac{1}{\varphi} Q\left(\frac{p}{P}\right)^{-\sigma}+f} & \text { if not exporting } \\
\frac{p Q\left(\frac{p}{P}\right)^{-\sigma}+p^{*} Q^{*}\left(\frac{p^{*}}{P^{*}}\right)^{-\sigma}}{\frac{1}{\varphi} Q\left(\frac{p}{P}\right)^{-\sigma}+\tau \frac{1}{\varphi} Q^{*}\left(\frac{p^{*}}{P^{*}}\right)^{-\sigma}+f+f_{x}} & \text { if exporting. }
\end{array}\right.
$$

Lemma 1. Measured labor productivity ( $\rho)$, contingent on export status, is continuous and increasing in marginal productivity $(\varphi)$.

Proof. Insert prices (e.g. $p=\frac{w}{\varphi} \frac{\sigma}{\sigma-1}$ on the home market) and differentiate wrt. $\varphi$.

The new theoretical measure (measured labor productivity) is positively related to marginal productivity, the conventional theoretical productivity measure in the literature. However, this is only the case for a given export status (pure domestic or export-active). Indeed, for the export-indifferent firm, measured labor productivity drops when switching status from nonexporting to exporting.

\footnotetext{
${ }^{2}$ Following the literature, we impose parameter restrictions such that there is partitioning into exporters and non-exporters.
} 
Proposition 1. The export-indifferent firm's measured labor productivity $(\rho)$ over all units sold is lower when it is export-active than when it is a purely domestic firm.

Proof. Denote variables of the export-indifferent firm by $\sim$. Using the productivity expressions and the fact that $\tilde{\Pi}^{\operatorname{Exp}}=0 \Leftrightarrow p^{*} Q^{*}\left(\frac{p^{*}}{P^{*}}\right)^{-\sigma}=$ $w f_{x}+\tau \frac{w}{\varphi} Q^{*}\left(\frac{p^{*}}{P^{*}}\right)^{-\sigma}$ from (2), it follows for measured labor productivity of a purely domestic, $d$, and export-active, $x$, export-indifferent firm that

$$
\begin{aligned}
\tilde{\rho}^{d} & >\tilde{\rho}^{x} \\
& \Longleftrightarrow \frac{p Q\left(\frac{p}{P}\right)^{-\sigma}}{\frac{w}{\varphi} Q\left(\frac{p}{P}\right)^{-\sigma}+w f}>\frac{p Q\left(\frac{p}{P}\right)^{-\sigma}+w f_{x}+\tau \frac{w}{\varphi} Q^{*}\left(\frac{p^{*}}{P^{*}}\right)^{-\sigma}}{\frac{w}{\varphi} Q\left(\frac{p}{P}\right)^{-\sigma}+\tau \frac{w}{\varphi} Q^{*}\left(\frac{p^{*}}{P^{*}}\right)^{-\sigma}+w f+w f_{x}} \\
& \Longleftrightarrow \frac{1}{\sigma-1}\left(\frac{w}{\varphi}\right)^{1-\sigma}\left(\frac{\sigma}{\sigma-1}\right)^{-\sigma} Q P^{\sigma}-w f>0 \\
& \Longleftrightarrow \tilde{\Pi}^{\operatorname{Dom}}(\varphi)>0 .
\end{aligned}
$$

Corollary 1. Ranked by marginal productivity, $\varphi$, there exists a range of firms around the export-indifferent firm such that all exporters in this range have lower measured labor productivity than the non-exporters included.

Proof. Follows from Lemma 1 and Proposition 1.

Crucial for the above results are the empirically relevant fixed costs of exporting, $f_{x}$, such as the administrative burdens or costs of maintaining a distribution network. Fixed costs, and in particular, the fixed costs of exporting, are a central element of the new theory and are well established in the empirical literature, e.g., Roberts and Tybout (1997); Lawless and Whelan (2008), Eaton et al. (2008).

The intuition for our finding is as follows: The firm that is just indifferent towards starting to export makes positive profits on the home market; otherwise it would have left the industry to start with. The same is true 
for several of its neighboring non-exporting firms that have higher marginal costs, but still make positive profits on the home market. They all have an operating surplus that more than covers their fixed costs of home production: i.e., measured labor productivity exceeds $w$. Consider a situation where the indifferent firm switches from non-exporting to exporting. Then we have added a zero-profit activity (namely exporting) to an otherwise profitable

firm. In particular, the operating surplus that the export-indifferent firm can make on the foreign market suffices to exactly cover the fixed costs of exporting: i.e., measured labor productivity on the export activity equals $w$. Building the average across all sold units (i.e., the profitable domestic sales and the zero-profit foreign sales), the indifferent firm's measured labor productivity must fall when switching status from non-exporter to exporter.

\section{Implications for empirical research}

Bringing the theoretical productivity measure in line with empirical work, we have shown that the theory suggests that for certain countries, industries, or periods, it might well be the case that groups of non-exporters in an industry display higher measured labor productivity than groups of exporters in the same industry. Whether this reversal of the exporter productivity premium shows up in country- or industry-wide studies based on firm-level data, will depend on the underlying distribution of marginal productivity and the size of fixed export costs. In this light, the exceptions to the empirical regularities on exporter productivity premia may deserve further examination. For example, Hansson and Lundin (2004) find for Sweden a negative exporter productivity premium. More examples of such exceptions are reported in Greenaway and Kneller (2007) and Wagner (2007). These results have previously been thought to go against the theoretical prediction.

Furthermore, our results provide a novel perspective on pre- and post- 
entry productivity differences, related to the causality between export status and firm productivity, i.e., learning from exporting. Our paper suggests that when comparing measured labor productivity and not marginal productivity, the theory predicts the existence of pre-entry productivity advantages of future exporters compared to future non-exporters, yet post-entry measured labor productivity - on the individual firm level - should, ceteris paribus, drop. Such an effect will distort measures of learning effects. In line with our theoretical prediction, the empirical literature consistently finds pre-entry differences, yet for post-entry differences the evidence is mixed, see, for example, Greenaway et al. (2005) or the surveys of Greenaway and Kneller (2007) and Wagner (2007).

\section{Conclusion}

The present note has shown that the workhorse model of heterogeneous firms trade, Melitz (2003), does contain the prospect of a negative exporter productivity premium. Our result highlights that predictions derived from the theory have to take account of fixed costs in order to become compatible with the available empirical evidence and that an explicit treatment of fixed and variable costs is needed when examining firm productivity.

\section{References}

Bernard, A. and J. Jensen (1995), Exporters, jobs and wages in US manufacturing: 1976-1987, Brooking Papers on Economics Activity, Microeconomics, pp. 67-119.

Eaton, J., S. Kortum and F. Kramarz (2008), An Anatomy of International Trade: Evidence from French Firms, NBER Working Paper, No. 14610. Greenaway, D., J. Gullstrand and R. Kneller (2005), Exporting May Not 
Always Boost Firm Level Productivity, Review of World Economics, Vol. 141 (4), pp. 561-582.

Greenaway, D. and R. Kneller (2007), Firm Heterogeneity, Exporting and Foreign Direct Investment, The Economic Journal, Vol 117, pp. 134161.

Hansson, P. and N.N. Lundin (2004), Export as an Indicator on or Promoter of Successful Swedish Manufacturing Firms in the 1990s, Review of World Economics, Vol. 140 (3), pp. 415-445.

Lawless, M. and K. Whelan (2008), Where Do Firms Export, How Much, and Why? University College Dublin, School of Economics, Working Paper, WP08/21.

Melitz, M.J. (2003), The Impact of Trade on Intra-industry Reallocations and Aggregate Industry Productivity. Econometrica, Vol. 71 (6), pp. 1695-1725.

Roberts, M.J. and J.R. Tybout (1997), The Decision to Export in Colombia: An Empirical Model of Entry with Sunk Costs, American Economic Review, Vol. 87 (4), pp. 545-564.

Wagner, J. (2007), Exports and Productivity: A Survey of the Evidence from Firm-level Data, The World Economy, Vol. 30 (1), pp. 60-82. 


\section{Economics Working Paper}

2009-11 Torben Sørensen and Rune Vejlin: The Importance of Worker, Firm and Match Fixed Effects in the Formation of Wages

2009-12: Nisar Ahmad: State Dependence in Unemployment among Danish Immigrants

2009-13: Nisar Ahmad and Rayhaneh Esmaeilzadeh: Immigrant-Native Differences in Earnings Mobility Processes: Evidence from Canadian and Danish Data

2009-14: Nisar Ahmad and Michael Svarer: The Effect of Sanctions and Active Labour Market Programmes on the Exit Rate From Unemployment

2009-15: Martin Paldam and Erich Gundlach: The religious transition - A long-run perspective

2009-16: Torben M. Andersen and Joydeep Bhattacharya: Unfunded pensions and endogenous labor supply

2009-17: Hristos Doucouliagos and Martin Paldam: Development Aid and Growth: An association converging to zero

2009-18: Christian Bjørnskov and Martin Paldam: The spirits of capitalism and socialism. A cross-country study of ideology

2010-1: $\quad$ Laurent Callot and Martin Paldam: Natural funnel asymmetries. A simulation analysis of the three basic tools of meta analysis

2010-2: $\quad$ Allan Sørensen: Welfare Effects of Trade Liberalization with Intra-industry Reallocations: The Importance of Preferences and Market Failures

2010-3: $\quad$ Marianne Simonsen, Lars Skipper and Niels Skipper: Price Sensitivity of Demand for Prescription Drugs: Exploiting a Regression Kink Design

2010-4: $\quad$ Torben M. Andersen and Allan Sørensen: Product market integration, rents and wage inequality

2010-5: John Kennes and Daniel le Maire: Coordination Frictions and Job Heterogeneity: A Discrete Time Analysis

2010-6: $\quad$ Philipp J.H. Schröder and Allan Sørensen: The Theoretical Equivalent of Empirically Measurable Exporter Productivity when Firms are Heterogeneous 